\title{
How to Inherit the National Culture of Music in Music Courses
}

\author{
Yi Ji \\ School of Music and Dance \\ Qujing Normal University \\ Qujing, Yunnan, China 655011
}

\begin{abstract}
The national culture has always been one focus of the development and ideological battles of all countries. Under the complex international situation in the world today, all the Chinese people need to consider the question namely how to maintain the purity of national culture in a variety of diverse values. As one important form of national culture, the national music culture deeply performs Chinese culture. However, with the development of education in recent years, the education of national music culture has declined. Therefore, as the main front of developing national music culture, what should schools do? As the centre of inheriting national music culture, what should students do? Here the question namely how to inherit national culture of music will be specifically analyzed in this paper.
\end{abstract}

Keywords-national music; culture; develop; inherit; students; teaching mode

\section{INTRODUCTION}

In recent years, with the development of economy in China and the improvement of Chinese people's living conditions, the strategy of building a culturally strong country is put forward in China. The contradiction between people's increasing material and cultural needs and the low productivity is gradually emerging. However, with the further development of market economy in China, the unhealthy ideas such as seeking nothing but profit and being anxious to get instant benefits have gradually spread. Everything is connected with interest, whereas far from enough and good efforts have been done to inherit culture. Therefore, this paper will mainly elaborate the ways to inheriting the national culture of music.

\section{THE CURRENT STATUS OF INHERITING NATIONAL Music Culture In Music Courses}

\section{A. Not Enough Emphasis from School}

Reviewing the development history since China's reform and opening up, it is easy to find that little emphasis has been laid on music teaching in China. On one hand, school has always been an important supporter for inheriting national culture and especially for the inheriting of national music culture. For another, the fact is that all schools in China haven't attached much attention to music teaching. In the nine years compulsory education, the middle and high schools except the primary school hardly set music courses. Firstly, it can be noticed from the teaching hours of music that many music courses are set up from the first grade to the fourth grade in most primary schools. But another scene is seen in middle school: pursuing for high graduation rate, leaders in middle school reduce computer experiment courses, outdoor courses such as PE and greatly cut music courses even conceal it in some good provincial middle schools. The situation is almost same in high schools: according to schools' requirement, culture courses such as music is reduced or taken by other courses. All the above scenes illustrate that the reduction of music courses results from schools' less attention on music education.

\section{B. The Deficiency of Personnel and the Aging of Methods in Music Teaching}

The less attention that the relevant education departments paid to music education leads to the trend of music courses gradually withdrawing from middle and high schools. As this trend continues to deepen, the music teachers' consciousness of being neglected begins to quit jobs and to leave schools. This makes the deficiency of music personnel even worse. Some music scholars are not qualified for teaching, which is one important reason for the deficiency of music teachers. Another significant reason is that schools' less attention leads to a limited recruitment for music teachers and some schools even strictly control the recruitment. What's more, the aging methods of music teaching are another disappointing situation in China. The music teachers in service are as old as twenty years' experience. Hence, they lean to teaching in traditional methods but students tend to have a low interest. Music teachers sometimes have to let things drift because schools do not pay money, attention, energy or time to music. Now, in China's music courses, seldom students are listening carefully except the one who is interested in music.

\section{A Brief Description on the Setting of Professions and its Reasons in the Contemporary Universities of China}

The professions in universities of China are focusing on application. Professions of art are few and that of national music culture are especially fewer. The above situation in China can date back to 1840 . By reviewing the past hundred years, it is clearly seen that China had been enslaved by imperialist countries and several generations had made painstaking efforts for survival and establishing a strong country. Therefore, a number of enlightened scholars introduce the advanced technology from abroad and establish a group of 
schools aiming to learn from abroad. Till now, for developing economy, the professions in universities are focusing on that of science, which contributes to the decline of art majors. Professions of national music culture are very few and even aren't set in some local universities. Moreover, children in China do not choose professions independently but the parents who are deeply affected by the traditional thoughts and think professions of science is easy to find jobs dominate the choosing. All this conducts to less students majoring art and thus a vicious circle of national music teaching.

\section{THE SignifiCANCE OF INHERITING NATIONAL MusiC CulTure in Music Courses}

The general secretary of the country, Xi Jinping, has stressed a thorough study on national culture in cultural forums and the importance of preventing the vicious force in ideology. With the growth of economy, Chinese people begin to treasure national culture in which the national music culture is an important one. In the popularization and promotion of national music culture, good ideological works done in schools and educational institutions are most important. The music courses are not only for inheriting national music culture but also realistic needs for propagating China's extensive and profound national culture as well as era calls of people with the economical growth. As the main front of cultural inheritance, schools should voluntarily assume the responsibility of inheriting culture. The importance of inheriting the culture of national music in the music courses is in the following: firstly, implanting the national culture into students from the education stage, and improving their recognition for national music culture so that they can praise the profoundness of national culture. Students should propaganda the Chinese national culture and play the master's role in cultural transmission and inheritance. Moreover, properly leading the ideology of adolescents and undergraduates and thickening the mass foundation of national music culture in campuses. No matter in life or in career, people with the accomplishment in national music culture could face everything with courage and improve personal comprehensive quality.

\section{THE STRATEGIES AND SUGGESTIONS OF INHERITING NATIONAL Music CUlTuRE IN Music COURSES}

The development of China's economy has put forward corresponding requirements of the times. Economy determines superstructure. People's growing cultural needs and the low cultural productivity has become a long-term contradiction in China. With the decline of the inheritance of national music culture in campuses, more requirements of the career have been proposed. Consisting of fifty-six ethnic groups, Chinese nation has created a spectacular cultural treasure, in which the music culture is a shining pearl. Therefore, the inheritance of national music culture is not just learning pop songs but deeply understanding the real connotation and inner strength. The question "how to carry out the inheriting" can be discussed from the following aspects:

\section{A. To Lead Students to Interest in China's National Music}

There are various reasons why students are not interested in national music. In order to resume students' interest in traditional music, we should do something from the aspects as follows:

\section{1) Vigorously Disseminating the National Music Culture and Its Historical Origin}

It should be clearly known that students' unknown for the history of national music culture partially accounts for their dislike towards national music. Comparing with the present pop music, students know the background of the famous stars and choose the music types they like. This way of transmission also is suitable for the transmission of national music. Therefore, in the music classes, teachers should elaborate the formative process, historical origin, and the difficulties and setbacks that Chinese nation has experienced to create national music today for students. On one hand, in order to make the class more effective, teachers should show some rare historical materials and combine the creation of national music with the history they have learned. On the other hand, teachers should explain the environment of creating national music, the twists and turns and the development in the new era. In selecting the teaching materials, teachers should start from students' characteristics and aptitudes. In a word, the creation and maturity of national music culture in thousands of years is a difficult and tortuous process, which should be realized by students.

\section{2) To Regularly Organize Activities of National Music} Culture

The accumulation of all cultures is commendable because of their survival after experiencing the thorns of history, especially the survival of Chinese national music culture. To regularly organize activities of national music culture is an approach to vividly show the precious heritage. By showing the heritage of national music, students can not only realize the difficulties in accumulating the music culture, but also make them interest in national music. The activities should not limit to the singing but should represent the history and obey the law of its development. Therefore, it is necessary to hold the activities according to the requirements of the times and the innovating mode.

\section{B. To Design Various Teaching Methods and to Increase Students'Learning Enthusiasm}

Seeing from the past methods in national music teaching, a blind and instilling one is adopted. Neglecting the feelings of students, teachers instill a large amount of music knowledge into their brains and are not aware of the results. On the other hand, students are learning for scores and without thinking of music's meaning. This kind of teaching mode makes both teachers and students passive, and generates no communication or feedbacks between them. With the development of the age, this teaching mode has been unable to adapt itself to the contemporary education system especially unable to meet the requirements of national music culture. Therefore, teachers should change the teaching mode according to the actual situation, and try to improve the teaching quality by designing unusual methods. For instance, we can teach national music by means of multimedia, and the advantages of this method are using and combining students' sensory system with their organs, indirectly improving 
students' efficiency and making them deeply understand the uniqueness of national music culture. In addition, multimedia also helps students associate the music, free their imagination and enhancing their appreciation for music.

\section{To Strengthen the Positive Role Teachers Played in the Teaching Process of National Music Culture}

It should be clearly noticed that in the process of spreading national music culture, students are the centre in its inheriting but teachers' job is to teach them in great details and insure students' understanding the connotation of national music culture. Then the expected inheritance is achieved.

\section{CONCLUSION}

Whether the national culture of music in China can be well spread, inherited and developed is directly related to the prosperity and cohesion of the Chinese nation. The unfailing hard and soft power determines a country's prosperity, in which the soft power is partially embodied in the spread and development of national music culture. The national music is the pioneer banner of national economy and development. Only lifting up the banner with national efforts can the Chinese pluck up their courage to develop socialism with Chinese characteristics and can China surge ahead in the changeable trend of world's development. As the central part in inheriting national music culture, the students should spare no effort to learn and contribute to the national music culture. Meanwhile, the relevant education institutions and schools should address enough attention to national music, and search a brand new teaching mode to teach students so as to make them better inherit the culture and to diversify the Chinese music culture.

\section{REFERENCES}

[1] Wu Jirong. The Importance of Regarding Chinese Music Culture as the Mother Tongue in the Background of New Curriculum --- A Discussion on "Developing National Music" and "Understanding Multi Cultures" in the Course Standard for Music [J]. Children's Music, 2004(2):40-42

[2] Sun Jing. A Discussion on How to Inherit National Music Culture in Music Courses [J]. Contemporary Music, 2016(2) 